\section{Refresher Courses for Science Teachers}

Termination of a student's normal course of study often brings to an abrupt end his active connexion with the university. In the case of science teachers, this is particularly undesirable, for it is important that the rapid developments which are taking place in their subjects should be fully discussed between school and university teachers, especially in relation to teaching methods. With these considerations in view, a ten-day course on modern aspects of chemistry was recently held at the University College of North Wales, Bangor, in co-operation with the Welsh Department of the Board of Education, one of the inspectors of which, Dr. D. M. Williams, assisted in the organisation of the course. Summaries were given of recent work on atomic structure, valency theory and its application to problems concerning the structure and reactions of some inorganic and organic compounds, the electro-chemistry of solutions, and the chemistry of natural and synthetic products of special interest; lectures and experiments were included illustrating advances in the theory and practice of $p \mathrm{H}$ determination, indicators, electrometric titrations, distillation, and chromatography, together with a demonstration of glass-blowing technique, a show of scientific films and a display of modern books, dealing especially with the subjects selected. While it was apparent that the teachers attending the course derived benefit and interest from it, the discussions proved most stimulating also to the University personnel who participated. The course was conducted by Prof. E. D. Hughes and Drs. W. R. Angus, I. Dostrovsky, J. Graham and D. R. Llewellyn, assisted in the experimental work by Dr. F. Brown, Mr. T. R. Jacobs, and senior research students; Prof. C. W. Davies and Dr. W. C. Evans, of University College, Aberystwyth, gave special lectures.

\section{Library Service in Industry}

A WELL-ATTENDED conference on "The Works Library", organised at Sheffield on March 27 by the Northern Branch of the Association of Special Libraries and Information Bureaux, was designed to help the budding works librarian to appreciate the scope of his work and the resources at his disposal. The chairman of the Conference, Mr. W. H. Higginbotham, chairman of Messrs. Edgar Allen and Co., Ltd., at the opening session, when the Association was welcomed by the Lord Mayor of Sheffield, emphasized the extent and diversity of knowledge required in industry and the importance of ensuring at all levels a sufficiency of knowledge and specialized information for the successful operation of an industrial or business undertaking, and of providing for its co-ordination and combination into an effective working tool. This is the essential task of the Association, and in the two papers presented at the morning session, "Pages from the Diary of a Steel Works Librarian" and "A Special Library in the Steel Industry", Mr. G. H. Davison and Miss A. R. Osborne gave some account of the building up of a library and information service for the United Steel Companies, Ltd., and for Messrs. Thomas Firth and John Brown, Ltd. Mr. Davison's paper in particular covered a wide range of problems in the organisation and running of a firm's library ; Miss Osborne's paper was illustrated by lantern slides, and those attending the Conference had a further opportunity of seeing the actual functioning of the information service on the following morning when parties visited the Brown-
Firth Research Laboratories. Other delegates availed themselves of the invitation of Messrs. Edgar Allen \& Co., Ltd., to visit their works and laboratories. At the afternoon session Mr. E. N. Simons contributed a stimulating paper on "The Works Library of To-morrow", in which he suggested a number of probable trends in works library service during the next few decades. In the concluding paper, Mr. R. Brightman discussed "Reference Books for the Works Library", dealing with the needs of a library concerned with production rather than with research, and submitting a series of lists designed to help the novitiate in charge of such a library in the selection of his or her own desk tools, general reference books, technical reference books and single-volume textbooks of the 'refresher' type; in general he only included one-volume reference works.

\section{Recent Earthquakes}

OF the first three months of 1947, January was by far the most seismic. During January there were seven world-recorded earthquakes, besides minor shocks in many parts of the earth, including two near Switzerland and nineteen in New Zealand. The Americas, the Aleutian Islands and Japan provided the world-recorded earthquakes, the greatest being on January 26 at $10 \mathrm{~h}$. $06 \cdot 7 \mathrm{~m}$. G.M.T. in western Nicaragua. This was a deep-focus earthquake, the focus being approximately $160 \mathrm{~km}$. deep. The first shock near Switzerland was on January 16 at 22h. $30 \mathrm{~m}$. G.M.T., and was felt with scale $\mathrm{V}$ at Stein am Rhein, and the second was on January 24 at 2h. $30 \cdot 5 \mathrm{~m}$. G.M.x., being felt at Westalpen Savoie, France. Nineteen local earthquakes and tremors were felt in New Zealand, the greatest being on January 10 at $16 \mathrm{~h} .08 \cdot 8 \mathrm{~m}$. G.M.T. from $46 \cdot 5^{\circ} \mathrm{S} ., 164^{\circ} \mathrm{E}$., which was felt with Modified Mercalli Scale IV at Puysegur Point.

During February there were two world-recorded earthquakes : on February 10 and 24, the latter having its epicentre in Japan. Several local tremors occurred, one of the largest being that on February 17 at $00 \mathrm{~h} .13 \mathrm{~m}$. at Piémont, France, with strength 5-6, being felt as far as Marseilles, Nice and Grenoble.

In March a strong earthquake occurred in China (epicentre $33.5^{\circ}$ N., $100 \cdot 0^{\circ}$ E.) on March 17 at $8 \mathrm{~h}$. $19.5 \mathrm{~m}$. G.M.T., and on March 26, an hour after the Wellington Observatory, New Zealand, had reported a strong earthquake out at sea, the first seismic sea wave some $30 \mathrm{ft}$. high rolled up on a 60 -mile stretch of the shore of Poverty Bay. This wrecked some waterside houses and shops at Gisborne and damaged some roads and bridges. At Gisborne some of the streets were $4 \mathrm{ft}$. under water. Half an hour after the first tsunami, a second arrived. Fortunately, the people on the sea-front saw the waves coming and got on to higher ground, so that no loss of life has been reported.

\section{Institution of Mechanical Engineers: Centenary Exhibitions}

IN connexion with the centenary celebrations of the Institution of Mechanical Engineers, during the week commencing June 8, an exhibition of Stephenson relics will be open to the public at the Institution at Storey's Gate, St. James's Park, London, S.W.1, during June 9-13 between 10 a.m. and 5 p.m. There are personalia and numerous prints, drawings and other material on loan from individuals and institutions.

A special exhibition is also being held in the Science Museum, South Kensington, during June 10-August 24 to commemorate the founding of the Institution 
in 1847. This exhibition, covering a century of mechanical engineering, is divided into several sections including mechanical plant for power stations ; locomotives; automobile, marine and aero-engines; hydraulic and handling machinery, etc. Important historical objects are shown in their appropriate galleries. Modern exhibits are displayed in Gallery 1. Scale-models made specially for this exhibition include the steam turbines of the R.M.S. Queen Elizabeth and a Southern Railway 'West Country' steam locomotive. Most exhibits, such as automobile and aero-engines, models of high-pressure boilers, steam and gasturbines, have never been shown in the Science Museum before.

\section{Conference on Liquid Helium}

A CONFEREnCE on liquid helium will be held at the Clarendon Laboratory, Oxford, during June 27-28. The programme includes discussions on the general and quantum theories of liquids (Prof. Max Born and Dr. H. S. Green respectively), the 'cage' model of a liquid (Dr. H. N. V. Temperley), zero-point energy of thin helium films (Prof. N. F. Mott), properties of helium films (K. R. Atkins, J. B. Brown and Dr. K. Mendelssohn) and Heisenberg's new theory of superconductivity (Prof. M. H. L. Pryce). Particulars of the conference can be ob tained from Prof. F. E. Simon, Clarendon Laboratory, Parks Road, Oxford.

Summer Symposium on Sound Absorption and Reverberation

The Acoustics Group of the Physical Society is holding a Summer Symposium on June 26 at the Royal Institute of British Architects. The discussions will open at 10 a.m. with a paper on "Panel Absorbents of the Helmholtz Type", by Prof. P. V. Bruel, of the University of Gothenburg. In the afternoon Mr. J. Moir, of the British Thomson-Houston Co., Ltd., will speak on "Reverberation Time as an Index of Room Performance". The meeting is open to all who are interested in acousties, but they are asked to notify the joint secretaries of the Acoustics Group at the offices of the Physical Society at 1 Lowther Gardens, Prince Consort Road, London, S.W.7, if they intend to be present, in order that necessary arrangements can be made.

\section{Scottish Summer Schools in Health Education}

$\mathrm{E}_{\mathrm{ACH}}$ year the Scottish Council for Health Education sponsors three residential summer schools at convenient centres. These schools are of interest to doctors, teachers, health visitors, nurses, youth leaders and others, who feel that integrated courses in physiology, psychology and social medicine will help them in their professional work. The schools are residential, last for fourteen days, and provide a total of twenty-seven lectures by men and women eminent in their special fields. Students may enrol for an elementary or intermediate course at the Universities of Edinburgh and St. Andrews, respectively, both from July 26 to August 9, or take an advanced course at Strathpeffer Spa during August 8-22. There are still a number of vacancies at the Edinburgh and St. Andrews schools, but only a very few at Strathpeffer, which, already, has attracted nearly a hundred students. Further information can be obtained from the Secretary, Scottish Council for Health Education, 3 Castle Street, Edinburgh, 2.

\section{University of London: Appointments}

THE following appointments in the University of London have been announced: Dr. Harry Jones, reader in mathematics at the Imperial College of Science and Technology, to the University chair of mathematics tenable at the College as from October 1, 1946 ; Dr. Alan Kekwick, to the University chair of medicine tenable at Middlesex Hospital Medical School as from October 1, 1946 ; Mr. M. E. L. Mallowan, to the University chair of western Asiatic archæology tenable at the Institute of Archæology as from May 1, 1947; Mr. Mallowan has conducted excavations at Arpachinah, the first settlement of the Tel Halaf culture to be scientifically excavated, also at Chagar Bazar and in the Tel Brak district; Dr. H. W. Miles, during 1943-46 adviser and senior lecturer in agricultural entomology in the University of Bristol, to the University chair of horticulture tenable at Wye College as from May 1, 1947 ; Mr. R. S. Sayers, during 1935-45 lecturer in economics at Pembroke, Exeter and Corpus Christi Colleges, Oxford, to the Sir Ernest Cassel chair of economics with special reference to banking tenable at the London School of Economics as from May 1, 1947; Mr. Herbert Tout, senior lecturer in economics at the University of Bristol, to the University readership in political economy tenable at University College as from October 1, 1947 ; Dr. W. J. Hickinbottom, since 1927 lecturer in chemistry in the University of Birmingham, to the University readership in organic chemistry tenable at Queen Mary College as from October 1, 1947; Dr. E. S. Horning, formerly of the permanent scientific staff at the Imperial Cancer Research Fund Laboratories, to the University readership in experimental pathology tenable at the Royal Cancer Hospital as from May 1, 1947 ; Dr. F. C. Tompkins, lecturer at King's College, to the University readership in physical chemistry tenable at the Imperial College of Science and Technology as from October 1, 1947.

The title of professor emeritus of chemistry in the University has been conferred on Dr. James F. Spencer on his retirement from Bedford College. The title of professor of comparative education in the University has been conferred on Dr. J. A. Lauwerys in respect of the post held by him at the Institute of Education.

The degree of D.Sc. has been conferred on O. V. S. Heath (Imperial College of Science and Technology); and S. S. Joski (University College).

\section{Announcements}

Sir LIONEL WHitBY, regius professor of physic in the University of Cambridge, has been elected master of Downing College, Cambridge, in succession to the late Sir Herbert Richmond.

A NATrONAL meteorological service has been established in Portugal under the direction of Prof. H. Amorim Ferreira. The headquarters of the new service is Serviço Meteorológico Nacional, Largo de Santa Isabel, 2-Lisboa (Portugal).

THE following officers were elected at the annual general meeting of the Society for Endocrinology held at University College, London, on May 29: Chairman : Dr. A. S. Parkes; Secretary: Dr. S. J. Folley, National Institute for Research in Dairying, Shinfield, Nr. Reading ; Treasurer : Dr. C. W. Emmens ; Editor of the Society's Proceedings : Prof. S. Zuckerman; Members of Committee : Dr. P. M. F. Bishop; Dr. C. H. Gray; Mr. P. C. Williams; Prof. F. G. Young.

Erratum. In the communication "TemperatureDependence of Magnetic Susceptibility of Annealed and Cold-worked Copper" (Nature, April 19, p. 537), par. 2, line 4, for " 0.005 per cent" read " 0.0005 per cent". 